\title{
WSPÓŁCZESNY STEREOTYP POLAKA I UKRAIŃCA W OPINII STUDENTÓW FILOLOGII UNIWERSYTETU ŁÓDZKIEGO (NA PODSTAWIE BADAŃ ANKIETOWYCH)
}

Słowa kluczowe: stereotyp Polaka, stereotyp Ukraińca, językowy obraz świata, ankieta

Streszczenie. Artykuł przedstawia rekonstrukcję - na materiale 394 ankiet - współczesnych stereotypów Polaka i Ukraińca w środowisku studentów Wydziału Filologicznego Uniwersytetu Łódzkiego. Zaproponowano analizę kilku punktów obszerniejszej ankiety, a mianowicie prośbę o podanie: definicji Polaka/Ukraińca; wyrażeń o tym samym odniesieniu, co Polak/Ukrainiec; cech „typowego" i ,prawdziwego" Polaka/Ukraińca. Ujawniono, iż w studenckich definicjach nazwy Polak/Ukrainiec częściej stosuje się kategoryzację geograficzną, etniczną, narodowościową, natomiast rzadziej używa się językowej, etycznej, tożsamościowej. Za odpowiedniki wyrazu Polak studenci uważają leksemy Polaczek, rodak, krajan, nasz, swój i in., a zamiast słowa Ukrainiec podają nazwy: obcokrajowiec, cudzoziemiec, sasiad, brat ze Wschodu i in. Obraz „prawdziwego” Polaka/Ukraińca jest bardziej pozytywny niż obraz „typowego” reprezentanta narodowości. Zarówno dla Polaka, jak i Ukraińca stereotypowy obraz wyłoniony z danych ankietowych jest ambiwalentny. Uwzględniono wpływ stereotypów narodowościowych na nauczanie języka polskiego jako obcego oraz możliwość zastosowania uzyskanych danych w glottodydaktyce.

\section{STAN I METODOLOGIA BADAŃ}

W nurcie badań etnolingwistyki kognitywnej mieści się koncepcja językowego obrazu świata oraz wpisane w jej ramy zagadnienia stereotypów językowych (np. Polaka, Ukraińca). Ponieważ w lingwistycznych badaniach stereotypów nadrzędna jest rola języka potocznego, jako materiał badawczy zalecane są m.in. dane ankietowe (Bartmiński 2014), które dostarczają bogatych informacji na temat sposobów kategoryzacji, wartościowania i interpretowania obiektu. Dane te pozwalają również uwzględnić podejście auto- i heterostereotypowe, co z ko-

*dyka.olya@gmail.com, Narodowy Uniwersytet Lwowski im. Iwana Franki, Wydział Filologiczny, Katedra Filologii Polskiej, ul. Uniwersytecka, 1, 79-000 Lwów. 
lei umożliwia zbadanie wyobrażeń o sobie i innych w świadomości językowej nosicieli stereotypów (Bartmiński 2006). Badaniom ankietowych autostereotypowych wyobrażeń (o Polaku) i heterostereotypowych wyobrażeń o Ukraińcu w językoznawstwie polskim i ukraińskim poświęcono już szereg prac. Stereotyp Polaka i Ukraińca wśród studentów lubelskich przedstawiono w pracach J. Bartmińskiego (Bartmiński 2006, 2014). J. Szadura zbadała autostereotyp Polaka (Szadura 1993). O stereotypowych profilach Polaka wśród studentów ukraińskich we Lwowie pisała A. Krawczuk (Krawczuk 2008). Różnice heterostereotypowego wizerunku Ukraińca zarysowujące się z odmiennej perspektywy geograficznej (Poznań i Lublin) zbadała E. Pacławska (Pacławska 2009). W 2019 roku O. Fyłypec również przeprowadziła badania nad stereotypem Ukraińca w środowisku studentów lubelskich i poznańskich, opisując wpływ czynnika geograficznego na postrzeganie Ukraińca i zmiany zachodzące na przestrzeni 10 lat (Fyłypec 2020), a także zbadała etnostereotypowe cechy Polaka i Ukraińca wśród studentów rzeszowskich na podstawie przypisywanych im ,,przedmiotów charakterystycznych" (Fylypets' 2019) oraz cechy Polaka i Ukraińca w środowisku studentów toruńskich (Fylypets' 2019). Znane są prace na temat autostereotypu Polaka reprezentowanego w podręcznikach do nauki języka polskiego jako obcego (Dąbrowska 1998; Brzezowska 2008; Stankiewicz, Żurek 2010). Korelacji między językowym obrazem świata a nauczaniem języka polskiego poświęcony jest artykuł R. Piętkowej (Piętkowa 2007). Uwzględniając przeprowadzone w ciągu ostatnich 20 lat badania nad stereotypami wśród ich nosicieli o różnych miejscach zamieszkania, za godne uwagi uważamy badania nad najnowszym stereotypem Polaka i Ukraińca w środowisku studentów filologii Uniwersytetu Łódzkiego.

Celem niniejszych badań jest zrekonstruowanie stereotypu Polaka i Ukraińca w środowisku studentów Wydziału Filologicznego Uniwersytetu Łódzkiego w oparciu o dane ankietowe, a także wskazanie ewentualnej różnicy w postrzeganiu autostereotypowym (siebie) i heterostereotypowym (Ukraińców). Uzyskane dane umożliwią uwzględnienie najnowszych danych o stereotypach przy nauczaniu języka polskiego oraz tworzeniu nowych pomocy dydaktycznych.

Podstawę materiałową tworzą dane z przeprowadzonych w 2019 roku wśród studentów ${ }^{1}$ Wydziału Filologicznego Uniwersytetu Łódzkiego 394 (197 - dla autostereotypu Polaka i 197 - dla heterostereotypu Ukraińca) ankiet typu otwartego. Uwzględnia się odpowiedzi na 4 pytania ankiety ${ }^{2}$, z których materiał analizo-

${ }^{1}$ Wśród 197 respondentów Wydziału Filologicznego znalazło się: 43 studentów 1. roku, 46 studentów 2. roku i 27 studentów 3. roku studiów licencjackich kierunku filologia polska oraz 39 studentów 1. roku studiów licencjackich i 42 studentów 1. roku studiów magisterskich kierunku logopedia.

${ }^{2}$ Były to następujące pytania: Kto to jest Polak/Ukrainiec? Prosze podać wyrazy, których Pan(i) (albo ktoś inny) używa zamiast stowa Polak/Ukrainiec; Proszę podać cechy, które, Pani/Pana zdaniem, najlepiej charakteryzuja typowego Polaka/Ukrainca (takiego, jaki on/ona jest); Prosze podać cechy, które, Pani/Pana zdaniem, najlepiej charakteryzuja prawdziwego Polaka/Ukraińca. 
wany w niniejszym artykule obejmuje ponad 2000 jednostek badawczych (leksemy, połączenia wyrazowe, wypowiedzenia i ich części, definicje studenckie). Jako źródła weryfikacji materiału wykorzystuje się słowniki języka polskiego (USJP3 2003; WSO 2011; ISJP 2014; WSJP 2018; WSJP https://wsjp.pl/, [05.06.2020]; Broniarek 2005).

\section{ANALIZA MATERIALU}

\subsection{POLAK I UKRAINIEC W ŚWIETLE STUDENCKICH DEFINICJI ANKIETOWYCH}

W celu ujawnienia studenckich definicji etnonimu Polak i zawartych w nich sposobów kategoryzacji studentom zadano pytanie o treści Kto to jest Polak? Tylko jeden z respondentów $(0,5 \%)$ nie udzielił odpowiedzi na to pytanie. Analizie w tej rubryce poddajemy 196 studenckich definicji etnonimu Polak. Odzwierciedlają one różne sposoby kategoryzacji pojęcia Polak w świadomości respondentów: geograficzny, polityczny, etniczny, etyczny, narodowościowy, językowy oraz taki, który zawiera element wartościujący niezwiązany z którąś z wymienionych dotychczas kategoryzacji. Warto podkreślić, że szereg ujawnionych sposobów kategoryzacji etnonimu Polak różni się od sposobów definiowania tych leksemów w słownikach językowych ${ }^{4}$. Tak więc najczęściej - 85 razy $(43,4 \%)$ - w studenckich definicjach pojawia się kategoryzacja geograficzna, która oparta jest na kryterium miejsca zamieszkania i urodzenia Polaka. Są to definicje, w których kategoryzacja geograficzna obejmuje całe określenie Polaka lub jest pierwszym czy ostatnim komponentem definicji, łącząc się z innymi sposobami kategoryzacji. Respondenci piszą np.: Polak - mieszkaniec Polski ${ }^{5}(19)^{6}$, mieszkaniec kraju Nadwiślańskiego, osoba mieszkająca $w$ Polsce (8), osoba urodzona w Polsce (5) etc. Niektóre definicje leksemu Polak na pierwszym miejscu zawierają kategoryzację geograficzną, po której następuje kategoryzacja etniczna: osoba urodzona w Polsce, mająca rodziców Polaków (2); osoba zamieszkująca tereny Polski, osoba pochodzaca z Polski; osoba mieszkajaca

${ }^{3}$ Rozwiązanie skrótów znajduje się na końcu artykułu.

${ }^{4}$ Leksem Polak w słownikach języka polskiego jest definiowany w świetle kategoryzacji geograficznej, politycznej, etnicznej i narodowościowej: 'ktoś, kto pochodzi z Polski' (ISJP 2014, s. 158); 'człowiek narodowości polskiej, mieszkaniec Polski, obywatel tego państwa' (USJP 2003, s. 307; WSJP 2018, s. 660); 'osoba narodowości polskiej' (WSJP, https://www.wsjp.pl/index.php?id_ hasla=722\&amp;ind=0\&amp;w_szukaj=polak, [05.06.2020]).

${ }^{5} \mathrm{~W}$ artykule stosuje się formy zapisane przez ankietowanych.

${ }^{6} \mathrm{~W}$ nawiasach wpisujemy liczbę podanych przez respondentów definicji, wyrażeń o tym samym odniesieniu, co wyrazy Polak/Ukrainiec, cech Polaka/Ukraińca. Brak liczby oznacza, że jednostka pojawiła się tylko jeden raz. 
i urodzona $w$ Polsce, posiadająca obu rodziców Polaków. Dwie definicje reprezentują m.in. czynnik lokalizacyjny, według którego mieszkanie w Polsce nie jest konieczne: osoba mieszkajaca w Polsce lub za granica, ale majaca rodziców Polaków i posiada obywatelstwo polskie (KG, KEtn, KP); osoba mieszkająca w Polsce, ale również poza granica, identyfikująca się z Polska, myślę, że nie trzeba mieć rodziców Polaków, żeby być Polakiem (KG, KEtn, W). Kategoryzacja geograficzna jako pierwszy komponent definicji etnonimu Polak łączy się również z kategoryzacją tożsamościową na ostatnim miejscu w definicji: osoba żyjąca $w$ Polsce lub utożsamiajaca się z niq, jej kultura i historia; osoba mieszkająca na terenie Polski lub która urodzita się w Polsce bądź utożsamia się z narodem polskim etc.

W niektórych definicjach kategoryzacja geograficzna etnonimu Polak łączy się z polityczną, np: osoba urodzona w Polsce, posiadająca polskie obywatelstwo (5) etc. Kategoryzacja polityczna ${ }^{7}$ - ogólnie rzecz ujmując - pojawia się w 79 (40,3\%) studenckich definicjach etnonimu Polak zaproponowanych przez studentów filologii. Za kryterium polskości uznaje się w tych definicjach posiadanie obywatelstwa polskiego oraz bycie patriotą. Polak w świetle kategoryzacji politycznej to obywatel Polski (33), osoba posiadajaca polskie obywatelstwo (3). Studenckie definicje Polaka (47 razy (24\%)) przedstawiają kategoryzację etniczną. W jej ramach osoba będąca Polakiem powinna spełniać kryterium polskiego pochodzenia lub posiadania rodziców (czy jednego z rodziców) Polaków: osoba pochodzaca z Polski (16), osoba polskiego pochodzenia (3), czlowiek pochodzacy z Polski, znający język, obyczaje, kulturę (KEtn, KJ, KE), osoba pochodzaca z Polski, czująca się Polakiem (KEtn, KT) etc.

Charakteryzując Polaka, studenci proponują kolejne „kryteria polskości” - identyfikowanie siebie jako Polaka, poczucie więzi z Polską. Kryteria te leżą u podłoża kategoryzacji tożsamościowej, która w studenckich definicjach występuje najczęściej jako element drugi lub ostatni: mieszkańcy Polski lub osoby, które na state mieszkaja $w$ Polsce, ale posiadaja polskie obywatelstwo, uważaja się za Polaków (KG, KP, KT); osoba, która urodziła się w Polsce i której rodzice sq Polakami, która to osoba przyjęla język polski oraz kulturę polska za swoja (KG, KEtn, KJ, KT). Warto w tym miejscu podkreślić, że kategoryzacja tożsamościowa pojawia się w studenckich odpowiedziach 25 razy (12,75\%). Uwzględnienie w definicjach kategoryzacji narodowościowej przewiduje realizację kryterium posiadania narodowości polskiej. Łącznie kategoryzacja narodowościowa pojawia się w 22 (11,2\%) studenckich definicjach leksemu Polak, występując na pierwszym miejscu lub łącząc się z innymi sposobami kategoryzowania: osoba narodowości polskiej (10); osoba narodowości polskiej (3), mieszkająca w Polsce

${ }^{7}$ Polityczny sposób kategoryzowania etnonimu Polak jako podstawowy w studenckich definicjach wiąże się z kategoryzacją tożsamościową, narodowościową, językową, etniczną. W takich przypadkach etnonim Polak jest określany jako obywatel Polski lub osoba w jakiś sposób z Polska zwiazana (3) (KP, KT); obywatel Polski, osoba pochodzenia polskiego (4) (KP, KEtn); obywatel Polski, którego korzenie pochodza z tego kraju, który na terenie Polski (KP, KEtn, KG). 
(3) (KN, KG); osoba narodowości polskiej, przywiązana do swojej ojczyzny (4) $(\mathrm{KN}, \mathrm{KT})$. Kolejny zestaw definicji ankietowych $(19-9,7 \%)$ odzwierciedla wartościowanie ${ }^{8}$ leksemu Polak. Trzeba zauważyć, że element wartościujący w tych definicjach ma konotacje zarówno pozytywne, jak i negatywne. Polak, według studentów, to ten, co wie wszystko najlepiej, ciagle narzeka, jest ciagle niezadowolony; Janusz z grubym brzuchem; obywatel państwa polskiego, uważajacy się za lepszych od innych, żyjacych na świecie i przeklinajacy swoja naturę, bywa wykorzystanym (KP, W); osoba mieszkająca w Polsce, patriota, żyjący w kraju uważanym za biedniejszy niż kraje Europy Zachodniej [...] (KG, KP, KW) etc.

13 (6,6\%) studenckich definicji etnonimu Polak zawiera kategoryzację językową. Kategoryzacja ta realizuje kryterium znajomości języka polskiego przez osobę, którą można nazwać Polakiem. W studenckich definicjach leksemu Polak kategoryzacja językowa zajmuje pozycję drugorzędną: obywatel Polski, mieszkajacy na terenie kraju, majacy polskie korzenie lub obcokrajowiec, który ubiegat się o polskie obywatelstwo na określonych zasadach, postugujacy się językiem polskim (KP, KG, KEtn, KJ); osoba mieszkająca w Polsce, mówiąca w języku polskim, przestrzegajaca tradycji (2) (KG, KJ, KE); mieszkaniec Polski, obywatel o narodowości polskiej, mówiacy po polsku (KG, KP, KN, KJ) etc. Wśród ankietowych odpowiedzi wyodrębniamy również definicje z kategoryzacją etyczną $(13-6,6 \%)$. Zgodnie z nią Polakiem jest ten, kto deklaruje pozytywny stosunek do Polski, zna polską kulturę i historię. Studenci Wydziału Filologicznego Uniwersytetu Łódzkiego m.in. piszą: osoba kochająa swój naród, często narzekajaca na wszystko, co się da, w głębi serca dobra, życzliwa i pomocna (KE, W); sa to osoby, które czuja się obywatelami Polski, sa gotowi bronić swej ojczyzny i przestrzegać panujacy w niej zasad, norm prawa (KT, KP, KE) etc.

197 definicji nazwy Ukrainiec odzwierciedla ważne sposoby kategoryzacji etnonimu Ukrainiec: geograficzny, polityczny, narodowościowy, tożsamościowy, etyczny, etniczny, językowy oraz wartościowanie ${ }^{9}$. Warto odnotować, że specyfi-

\footnotetext{
${ }^{8}$ Niektóre definicje z oceną odzwierciedlają podmiot interpretujący i zakorzenioną w świadomości opozycję „swój - obcy/inny”. Tak więc implicytnie używanie słów - człowiek taki sam jak ja, mój, rodak wskazuje na autostereotypowe postrzeganie Polaka jako swojego, np. mój rodak, obywatel Polski; czlowiek, taki sam, jak ja, np. Ukrainiec, Czech, Stowak; dla mnie jest to rodak, na zachodzie traktowany jak tania siła robocza, złodziej i pijak [...] boi się tego, co obce i tego, czego nie potrafi zrozumieć, ale ogólnie stara się być gościnny etc. Jeden z respondentów wskazuje na to, że charakterystyka Polaka zależy od konkretnej osoby, np. jest to zależne od osoby, połowa społeczeństwa jest wyksztatcona i inteligentna, a druga - nie.

${ }^{9} 19(9,6 \%)$ studenckich definicji etnonimu Ukrainiec zawiera wartościowanie tej nazwy. W świetle tych definicji Ukrainiec to np. ktoś, kto zmaga się z wojna i wyjeżdża ze swojego kraju w poszukiwaniu lepszych warunków do życia etc. Jak już widać z wymienionych do tej pory definicji, studenci wspominają o wojnie na Ukrainie, pracach zarobkowych oraz emigracji. W niektórych studenckich definicjach wartościowanie Ukraińca występuje jako element dodatkowy, np. osoba z Ukrainy, która $w$ dzisiejszych czasach przyjechata do Polski, $w$ celu edukacji bąźz znalezienia pracy ze względu na trudna sytuację w ich kraju (KG, W) etc. Trzy studenckie definicje leksemu
} 
ka objaśnienia tego leksemu w słownikach ${ }^{10}$ ogranicza się wyłącznie do kategoryzacji etnicznej, geograficznej, politycznej, narodowościowej. Najczęściej (49,7\%) - na tle innych kategoryzacji - w studenckich definicjach leksemu Ukrainiec pojawia się kategoryzacja geograficzna, która określa miejsce zamieszkania i urodzenia Ukraińca. W świetle tej kategoryzacji leksem Ukrainiec jest definiowany jako mieszkaniec Ukrainy (24); osoba mieszkajaca na terenie Ukrainy (13); osoba, która urodziła się na Ukrainie (2); mieszkaniec Ukrainy, kraju sąsiadującego $z$ Polska. W 7 definicjach Ukrainiec jest określany jako sąsiad: sasiad Polaków, mieszkaniec Europy, mający stowiańskie korzenie (KG, KEtn); osoba ze Wschodu, zza naszej wschodniej granicy, sasiad geopolityczny (KG); jest to mieszkaniec Ukrainy, jednocześnie mój sasiad, obywatel innego kraju (KG, KP); osoba pochodzaca z Ukrainy, nasz sasiad (KEtn, KG) etc. W 64 (32,5\%) definicjach etnonimu Ukrainiec pojawia się kategoryzacja etniczna ${ }^{11}$, przy której określa się Ukraińca ze względu na posiadanie pochodzenia ukraińskiego lub rodziców o takim pochodzeniu: osoba pochodzaca z Ukrainy (26); osoba pochodzenia ukraińskiego. Kategoryzację polityczną ${ }^{12}$ zawiera $51(25,8 \%)$ studenckich definicji. Szereg definicji o takim sposobie kategoryzowania określa Ukraińca ze względu na posiadanie obywatelstwa ukraińskiego. Oto definicje etnonimu Ukrainiec o kategoryzacji politycznej jako podstawowej: obywatel Ukrainy (18); osoba będaca obywatelem Ukrainy (2); osoba, która posiada obywatelstwo ukraińskie (2).

21 razy $(10,7 \%)$ w ankietowych definicjach pojawia się kategoryzacja narodowościowa. Charakterystycznym kryterium dla tej kategoryzacji jest posiadanie narodowości ukraińskiej, np. Ukrainiec - osoba narodowości ukraińskiej (9); osoba innej narodowości niż narodowość polska. Jako składnik nadrzędny kategoryzacja narodowościowa pojawia się w takich definicjach nazwy Ukrainiec: osoba narodowości ukraińskiej i utożsamiająca się z nia (3) (KN, KT); człowiek

Ukrainiec z nadrzędnym elementem wartościującym świadczą o przyjaznym postrzeganiu Ukraińców przez Polaków: często postrzegani sa jako nasi słowiańscy przyjaciele, obywatel Ukrainy (W, KP); to człowiek, taki sam, jak ja, tylko narodowości ukraińskiej, a nie polskiej (W, KN) etc.

${ }^{10}$ Ukrainiec - 'ktoś, kto pochodzi z Ukrainy' (ISJP 2014, s. 903); 'obywatel Ukrainy' (WSO 2011, s. 970); 'nazwa osobowa od Ukraina' (WSJP, http://www.wsjp.pl/index.php?id hasla=44707\&amp;ind=0\&amp;w_szukaj=UKRAINIEC+), 'człowiek narodowości ukraińskiej, mieszkaniec Ukrainy, obywatel tego państwa’ (USJP 2003, s. 225; WSJP 2018, s. 48).

${ }^{11}$ Istnieją też definicje, w których kategoryzacja etniczna występuje jako element rozbudowanych definicji Ukraińca, np: mieszkaniec Ukrainy, osoba pochodzenia ukraińskiego o takiej właśnie narodowości (KG, KEtn, KN); osoba, której rodzice sa Ukraińcami, która urodziła się na Ukrainie lub posiada obywatelstwo ukraińskie, ale urodziła się w innym kraju (KEtn, KG, KP); osoba, która urodzita się i mieszka w Ukrainie, posiada ukraińskie obywatelstwo, korzenie, rodzinę (KG, KP, KEtn) etc.

${ }^{12} \mathrm{Na}$ pierwszym miejscu kategoryzacja polityczna znajduje się w następujących definicjach leksemu Ukrainiec: obywatel Ukrainy, człowiek jak każdy inny (KP, W); obywatel Ukrainy, osoba mieszkajaca w tym kraju, mająca ukraińskie korzenie (2) (KP, KG, KEtn); obywatel Ukrainy, mówiący w języku ukraińskim (KP, KJ) etc. Zatem kategoryzacja polityczna pojawia się w definicjach jako element drugorzędny: sa to osoby, które mieszkaja na terenie Ukrainy, obywatel mniejszości narodowej (KG, KP) etc. 
innej narodowości, obcokrajowiec, z własnym językiem, mający prawo do rozwoju oraz wolności narodowej (KN, KJ, KE). Warto podkreślić, że ostatnia definicja w ujęciu heterostereotypowym odzwierciedla zakorzenioną w świadomości binarną opozycję „,swój - obcy/inny”, zawierając wykładniki obcokrajowiec, człowiek innej narodowości. Jako ostatni komponent kategoryzacja narodowościowa występuje w takiej definicji leksemu Ukrainiec: osoba pochodzaca z Ukrainy, narodowości ukraińskiej (2) (KEtn, KN).

$13(6,6 \%)$ studenckich definicji zawiera również kategoryzację tożsamościową ${ }^{13}$, na którą składa się wymaganie od Ukraińca identyfikowania się albo poczucia więzi z Ukrainą. Występuje ona głównie jako składnik dodatkowy lub na ostatnim miejscu: osoba, która urodziła się na terenie Ukrainy lub czuje się, że należy do tego narodu (KG, KT); osoba obywatelstwa ukraińskiego lub osoba pochodzenia ukraińskiego, która identyfikuje się z ta narodowościa (KP, KEtn, KT) etc. Kategoryzację językową przedstawia 8 (4,06\%) studenckich definicji etnonimu Ukrainiec. Za kryterium ukraińskości respondenci uznają znajomość języka ukraińskiego. Należy wspomnieć, że kategoryzacja językowa występuje w definicjach tylko na ostatnim miejscu: mieszkańcy Ukrainy, osoby, które czuja się zwiazane ze swoim państwem, postugujące się językiem (KG, KT, KJ); osoba mieszkająca na Ukrainie, postugujaca się językiem ukraińskim (KG, KJ). W jednej definicji wspomina się też o znajomości języka rosyjskiego: jest to osoba, która urodzita się na Ukrainie, ma obywatelstwo ukraińskie, postuguje się językiem ukraińskim, rosyjskim, najczęściej prawostawny (KG, KJ, KE). Kategoryzacja etyczna, tak samo jak językowa, jest reprezentowana przez 8 (4,06\%) studenckich definicji, w których za Ukraińca uznaje się osobę deklarującą szacunek wobec Ukrainy, posiadającą znajomość kultury, historii ukraińskiej, poglądy religijne. W studenckich definicjach tego typu Ukrainiec to osoba pochodzaca z Ukrainy, znajaca tamtejsza kulturę, język, obyczaje (KEtn, KE); mieszkaniec państwa Ukrainy $w$ Europie Wschodniej o wyodrębnionych elementach, obrzędach, języku, historii, postugujacy się językiem ukrainskim (KG, KE, KJ) etc. Kategoryzacja etyczna występuje w studenckich definicjach jako składnik drugorzędny.

\subsection{WYRAŻENIA O TYM SAMYM ODNIESIENIU, CO WYRAZY POLAK/UKRAINIEC}

W celu ujawnienia upowszechnionych wśród studentów wyrazów, których używa się zamiast nazwy Polak, zadano im pytanie: Prosze podać wyrazy, których Pan(i) (albo ktoś inny) używa zamiast stowa Polak. Tylko 141 (71,6\%) stu-

${ }^{13} \mathrm{~W}$ jednej studenckiej definicji nazwy Ukrainiec kategoryzacja tożsamościowa występuje jako składnik nadrzędny: osoba, która czuje się związana z Ukraina jako krajem swojego urodzenia, swojej rodziny, bliskich, przodków (KT, KG, KEtn). 
dentów podało odpowiedź na to pytanie, a $56(28,4 \%)$ studentów nie zaproponowało wyrażeń o tym samym odniesieniu, co wyraz Polak. Najczęściej - wśród wyrażeń o tym samym odniesieniu ${ }^{14}$ - pojawia się leksem Polaczek (44). Studenci twierdzą: to stowo jest nacechowane negatywnie, ukazuje wady; złośliwie; kpiaco. Jeden słownik synonimów języka polskiego rejestruje ten wyraz z kwalifikatorem - 'pogardliwie' (Broniarek 2005, s. 532). Do odpowiedników wyrazu Polak studenci zaliczają również połączenie wyrazowe Polaczek-cebulaczek (3). Podając wyrażenie Polaczek-cebulaczek, jeden z respondentów pisze: osoba chcaca oszczędzić za wszelka cenę, nawet oszukując. W szeregu form fleksyjnych derywatów mieszczą się następujące wyrażenia o odniesieniu do słowa Polak: Polaczka, Polacy, Polaki. Pojawiają się też dwa wyrazy nazywające Polaka zagranicznego: Polonia, Polonus. Ostatni leksem (Polonus) też mieści się w słowniku, ale bez określonego kwalifikatora i znaczenia (Broniarek 2005, 532). Często w odpowiedziach studenckich pojawiają się następujące nazwy Polaka: cebulak (28), cebula (14), cebulaczek, cebulacy, buraczek. Młodzież nazywa cebulakiem osobę niewykształconą, wywodzącą się ze wsi oraz nieposiadającą kultury osobistej. Odpowiadając na pytanie, studenci często przytaczają antroponimy, wśród których znajdują się imiona męskie i żeńskie, które nie są neutralne, a odnoszą się do określonego typu Polaka/Polki: Janusz (42), Grażyna (29) (komicznie), Seba (6) (żartobliwie), Sebiks (2), Halina (2), Karyna (6), Dżesika (3), Brajan (2). Stosunkowo często respondenci podają zamiast etnonimu Polak wyrażenia odzwierciedlające zakorzenioną w świadomości dychotomię ,swój-obcy”: rodak (22), polaki-rodaki, krajan (3), przedstawiciel naszego ojczystego kraju, wasowe bracia, brat (4), siostra, bratanek. Wykładnikami opozycji „swój - obcy” są też zaimki, zaproponowane przez studentów do nazywania Polaka: nasz (8), swój (3), nasza (2), nasi. Dwukrotnie studenci podają rzeczowniki - pani/pani (2). Pojawiają się też określenia nacechowane pozytywnie: sąsiad (2), kolega, rodzina, kompan, rówieśnik, tutejszy, ziomek. Niektóre słowa dotyczą kategoryzacji politycznej, ponieważ nazywają Polaka tak: obywatel (17), patriota (6), narodowiec (2), ojczyzna, kraj. Z kategoryzacją polityczną łączą się również wyrazy nazywające Polaka ze względu na przynależność wspólnotową i etniczną: Europejscy, Stowianin (4), Stowianka (6), zachodni Stowianin (3) (nie do końca). Znajdujemy również przestarzałe nazwy Polaka: Lach (4), Lechita, Lechici, Laszek. Studenci podają też nazwy taksonomiczne: człowiek, kobieta (2), mężczyzna (2). Dziewięć razy pojawia się wyrażenie uwzględniające czynnik lokalizacyjny - mieszkaniec Polski (9), a także określenie - znad Wisty. W studenckich odpowiedziach są też nazwy mieszkańców miast i regionów: łodzianin, warszawiak, nadwiślanin.

${ }^{14}$ Studenckie odpowiedzi zawierają również odpowiedniki wyrazu Polak nacechowane ujemnie: pijak (5), złodziej (3), robak (2), cwaniak (2), bandyta, krętacz, nierób, idiota, opóźniony, brudas, leń, cham, dzban, prostak, somsiad (2) (to takie żartobliwe określenie z memów), nosacz (5). Ostatnia studencka nazwa nawiązuje do nazwy zwierzęcia, którego wyróżnia charakterystyczny nos. 
Jeden raz pojawia się wyraz katolik. Zebrany materiał ujawnia stereotypowe obrazy Polaczka-cebulaczka, cebulaka, buraczka, które oznaczają człowieka pochodzenia wiejskiego. Uwidacznia się utrwalony w świadomości młodzieży pejoratywny obraz „typowego” Janusza i Grażyny. Pojawiają się też nazwy o silnej emocjonalizacji oraz nazwy historyczne. Mniej upowszechnione okazały się obrazy Polaka-Europejczyka i Polaka-Słowianina. Niektóre z podanych przykładów nawiązują do tradycyjnych stereotypowych obrazów Polaka-patrioty i rzadziej do Polaka-katolika.

Studentom zadano analogiczne pytanie $\mathrm{w}$ ankiecie badającej wyobrażenia heterostereotypowe. Warto odnotować, że odpowiedziało na nie $112(56,8 \%)$ studentów, natomiast 85 (43,1\%) osób nie podało odpowiedzi. Wśród studenckich odpowiedników ${ }^{15}$ etnonimu Ukrainiec wyodrębniamy jednostki językowe odzwierciedlające opozycję „swój - obcy/inny”: obcokrajowiec (26), cudzoziemiec (6), obcy (2), inny, osoba z innego kraju. Można przypuścić, że na pojawienie się w studenckich odpowiedziach powyższych określeń Ukraińca wpłynęło geograficzne oddalenie Łodzi od granicy z Ukrainą. Dystans wobec Ukraińca odzwierciedlają też takie jednostki: ci ze wschodu, osoba ze wschodniej granicy, kresowiec, osoba mieszkająca na kresach. Z odpowiedzi wyłaniają się też wyrażenia o tym samym odniesieniu wskazujące na obraz Ukraińca-imigranta: imigrant (9), przyjezdny, uchodźca. Jedna wypowiedź studencka przemawia za tym, że obraz imigranta nie dotyczy jedynie Ukraińca: nie styszałam synonimów tego słowa, choć czasami $w$ mediach sq mianem imigrantów, ale nie dotyczy to tylko jednej narodowości. Część nazw Ukraińca sprowadza się do konotacji historycznych, np. kozacy (3) (historycznie), Rusek (14), Ruscy (2), ruski (5), rusin. 3 razy w odpowiedziach ankietowych pojawia się nazwa Banderowcy (3), przy której respondenci zaznaczają: obraźliwie na nacjonalistów; do niektórych Ukrainców nastawionych antypolsko. O przyjaznym postrzeganiu Ukraińca w środowisku studentów Wydziału Filologicznego świadczy szereg przykładów: wschodni bracia (2), brat। siostra ze wschodu, brat Stowianin (3). W 9 wskazaniach respondenci nazywają Ukraińca: sasiedzi ze wschodu (7), sąsiad Polski (2). O postrzeganiu Ukraińca w świetle edukacji przemawiają następujące odpowiedniki: erazmus (3), erazmusy, koleżanka ze studiów. Studenci filologii zamiast słowa Ukrainiec podają etnonim Rosjanin (4), Rosjanka, ale potem thumaczą: często to pomytka ze względu na postugiwanie się przez Ukraińców językiem rosyjskim. Dwóch respondentów uzasadnia przyczynę używania etnonimu Rosjanin: często mylone z Rosjanami; Ukraincy bywaja myleni z Rosjanami, jednak nie jest to synonim, a raczej wynika $z$ niewiedzy, uproszczen dotykajacych calego wschodu. Kolejny zestaw słów to antroponimy, uznawane przez studentów za wyrażenia o tym samym odniesieniu,

${ }^{15} \mathrm{~W}$ tej rubryce pojawiają się też takie same określenia Ukraińca, jak w przypadku pytania - Kto to jest Polak? Są to m.in. określenia z kategoryzacją polityczną - obywatel Ukrainy (5), obywatelka wschodu, kategoryzacją geograficzną - mieszkaniec Ukrainy (10), osoby z Ukrainy. 
co wyraz Ukrainiec: Swiettana, Iwan (2), Karyna (2), Saszka (3) (żartobliwie), Tatianka (żartobliwie), Borys. Być może obecność w odpowiedziach studenckich antroponimów jako odpowiedników nazwy Ukrainiec (szczególnie zdrobnień, np. Saszka, Tatianka) świadczy o bezpośrednich kontaktach z Ukraińcami. Trzy razy pojawia się określenie Ukraińca ze względu na częste używanie słowa „szo”: szoszon (3). Jeden respondent uzasadnia: mi znajomi thumaczyli, że to ze względu na powtarzane przez Ukraińców słowo „szo”, czyli nie ma być to określenie obraźliwe. Studenci podają też nazwy taksonomiczne: kobieta (2), mężczyzna (2), człowiek. Dwa razy w ankietach pojawiają się rzeczowniki - pan, pani. Odpowiedzi ankietowe zawierają także etnonimy Ukrainiec (8), Ukraińcy (2), nie Polak. Wartościowanie ujemne przedstawia wyraz brudas (3), przy którym respondent np. twierdzi: nie ja używam takiego określenia, ale styszałam je. Na tle zaproponowanych przez studentów odpowiedzi wyłaniają się heterostereotypowe obrazy Ukraińca jako obcokrajowca, Ukraińca-imigranta, Ukraińca-sąsiada. Nazwy historyczne świadczą o istnieniu niektórych historycznych wyobrażeń o Ukraińcu. Wśród odpowiedzi pojawia się stereotypowy obraz Ukraińca-kolegi ze studiów.

\section{3. „TYPOWY” I „PRAWDZIWY” POLAK/UKRAINIEC}

W celu ujawnienia cech „typowego" i „prawdziwego" Polaka poproszono studentów o udzielenie odpowiedzi na kolejne pytania badawcze: Proszę podać cechy, które, Pani/Pana zdaniem, najlepiej charakteryzuja typowego Polaka (takiego, jaki on/ona jest) oraz Proszę podać cechy, które, Pani/Pana zdaniem, najlepiej charakteryzuja prawdziwego Polaka. Wprowadzenie do pytań ankietowych modyfikatorów „typowy” i „prawdziwy ${ }^{16 ”}$ przewidywało również zbadanie różnic zarysowujących się między obrazem „typowego" i „prawdziwego” reprezentanta narodowości. Zebrany empirycznie materiał należy do różnych kategorii semantycznych, a więc odzwierciedla ważne dla polskiej młodzieży sfery życiowe, przez które jest postrzegany Polak i Ukrainiec. Wyróżnione z materiału ankietowego kategorie semantyczne nazywamy aspektami ${ }^{17}$, które moż-

${ }^{16}$ Celowość wprowadzenia modyfikatorów „typowy” i ,prawdziwy” do pytań ankietowych badających stereotypy uzasadnia się w np. w pracach J. Bartmińskiego (Bartmiński 2006), M. Nowosad-Bakalarczyk (Nowosad-Bakalarczyk 2002), A. Krawczuk (Krawczuk 2008). W uzualnej polszczyźnie czasami utożsamia się wyrazy ,typowy” i ,prawdziwy” i błędnie uważa się je za synonimy. Natomiast J. Bartmiński twierdzi, że modyfikator „typowy” świadczy o statystyczności, częstej powtarzalności, uogólnieniu badanego zjawiska, lecz modyfikator „prawdziwy” oprócz funkcji uogólnienia, pełni też funkcję modalną, czyli przedstawia informację o treści pożądanej, wyobrażeniowej, ujawnia to, co jest ważne dla ludzi (Bartmiński 2001).

${ }^{17}$ Do opisu młodzieżowych cech „typowego” i „prawdziwego” Polaka/Ukraińca używamy terminu ,aspekt” w ślad za polskimi etnolingwistami (np. Niebrzegowska-Bartmińska 2014, s. 77), 
na sprowadzić do następujących: komunikacyjno-psychicznego, kulturowego, politycznego, psychospołecznego, lokatywnego oraz fizycznego. Należy zaznaczyć, że na pytanie o „typowego” Polaka odpowiedziało 191 (96,9\%) studentów, a w $8(4,06 \%)$ ankietach nie było odpowiedzi. Aspekt komunikacyjno-psychiczny $^{18}$ jest reprezentowany przez 302 jednostki badawcze (leksemy, połączenia wyrazowe, wypowiedzenia i ich części). Autostereotypowy model „typowego" Polaka w zakresie tego aspektu jest ambiwalentny, jednak cechy o konotacji negatywnej (199) dominują nad cechami o konotacji pozytywnej (103). Przedstawiamy dalej cechy, które pojawiły się w odpowiedziach więcej niż 3 razy: zaradny (6), dumny (6), towarzyski (5), uśmiechnięty (4), uczciwy (4), odważny (3), zawzięty (3), poważny (3), pomystowy (3), sympatyczny (3), wesoly (4), szczery (4), pomocny (5), sprytny (4) etc. Dwie odpowiedzi zawierające wyrazy zawsze, czasami wskazują na typowość określonej cechy: miły (6) (czasami), zawsze sobie pora$d z a$ (4). Cechy „typowego" Polaka o zabarwieniu negatywnym są reprezentowane przez jednostki: nietolerancyjny (19), cwaniak (14), zazdrosny (14), skłonność do marudzenia (9), kłótliwy (7), zawistny (6), nieuczciwy (4), wiecznie narzekający (4), niezadowolenie z życia (3), awanturniczy (3), chytry (3), nerwowy (3), nieufny (3), uparty (3), egoista (3), pesymista (3) etc. Wyodrębniamy dwie odpowiedzi o konotacji negatywnej zawierające wskaźnik typowości cechy: ciagle narzekanie (13), zbyt często smutny (4). Niektóre z nich (rzadko, czasami, wiecznie) świadczą o charakterystyce przeciętnej: czasami zbyt mało spontaniczny, rzadko się do siebie uśmiechaja, wiecznie zirytowany. Wśród odpowiedzi na to pytanie pojawiają się przykłady, które mogą jednocześnie odnosić się do różnych aspektów. Do aspektu psychospołecznego odnoszą się 203 jednostki językowe charakteryzujące Polaka ze względu na tryb życia, sposób pracy, prowadzenia domu, rodziny etc. Cechy te jednocześnie zależą od psychicznych właściwości człowieka oraz aktywności społecznych. Najczęściej prezentuje ten aspekt cecha pracowity (41). Studenci również wskazują na cechę leniwy (21). O „pracowitości” „typowego” Polaka przemawiają również takie przykłady: jest chętny do pracy (2), pracują na swój sukces i życie, zapracowany, kombinuje jak zarobić, by się nie narobić. Wysokie notowania mają takie charakterystyki „typowego" Polaka: gościnny (35), oszczędny (13), skapy (12), rodzinny (5) etc. Na stereotypową cechę „typowego”

którego wyróżnienie implikuje materiał empiryczny. W literaturze przedmiotu oprócz terminu „aspekt” - 'domeny wyodrębnionej z określonego punktu widzenia' (Niebrzegowska-Bartmińska 2014, s. 77), używa się terminu „faseta” jako ogólnie przyjętej 'grupy klas odpowiadających jakiejś wspólnej charakterystyce' (Niebrzegowska-Bartmińska 2014, s. 77). W przeciwieństwie do zestawu aspektów, nabór faset jest stały.

${ }^{18}$ Te określenia „typowego" Polaka zawierają również słowa (np. Polacy, uważaja się, najczęściej) wskazujące na typowość cech: niestety Polacy to osoby, które uważaja się za kogoś lepszego (a nie jest tak), zamiast wspierać, cieszyć się z sukcesów innych (swoich znajomych), najczęściej zazdrościmy, jesteśmy źli, że ktoś wiedzie się lepiej; Polacy [..] to katolicy (choć wcale nie wynika to z głębokich przekonań, a z tradycji. W tych określeniach ujawnia się podmiot interpretujący (my, Polacy). 
Polaka picie alkoholu składa się 35 jednostek językowych typu pije alkohol (3), lubi alkohol (3), dużo pijacy (7). O chęci do zabaw „typowego” Polaka świadczą następujące cechy: rozrywkowy (2), imprezowicz, lubi imprezować, lubiacy zabawę. Na autostereotypowy model „typowego" Polaka składają się również cechy: czekający na pieniadze z nieba, chęć zarobku, chęć dotatniego życia, zależy bardzo na pieniadzach, za pieniadze zrobi prawie wszystko, dla narodu jeszcze więcej. Ostatnia cecha może odnosić się również do aspektu politycznego. Ze względu na różne semantyczne konfiguracje kolejne cechy też mogą uwzględniać inne aspekty, np. komunikacyjno-psychiczny: dbajacy tylko o siebie, niemartwiacy sie przyszłościa, mający podejście jakoś to będzie etc. Do aspektu politycznego ${ }^{19}$ odnosi się 35 jednostek określających ,typowego" Polaka ze względu na jego patriotyzm, postawę obywatelską, poczucie tożsamości oraz znajomość historii, hymnu. 16 razy pojawia leksem patriota (16). „Typowy” Polak to też konserwatysta (3), nacjonalista, narodowiec, bohaterski, dumny z polskiej historii (2), dumny ze swojego narodu, przywiązany do historii kraju, uważa Polskę za najlepsza, walczy o demokracje, szanuje symbole narodowe, przywiazany do kraju. Aspekt kulturowy przedstawia 37 jednostek badawczych używanych do określenia „typowego" Polaka ze względu na kulturę osobistą, szeroko pojętą inteligencję i przekonania religijne. W modelu autostereotypowym ,typowy” Polak jest uprzejmy (4), kulturalny, ale jednocześnie mało uprzejmy i nie potrafi się zachować. Przekonania religijne „typowego" Polaka są odzwierciedlone w takich jednostkach: religijny (4), katolik (3) (obecnie chyba coraz częściej niepraktykujacy), chrześcijanin, pobożny. O typowości przytoczonych cech świadczą odpowiedzi zawierające rzeczownik w liczbie mnogiej (Polacy), czasownik w liczbie mnogiej (chodza): Polacy chodza do kościoła, Polacy wierzacy (2). Wśród jednostek określających „typowego" Polaka ze względu na inteligencję mieszczą się również te o znaczeniu dodatnim i ujemnym: niewyksztatcony (3), bez zainteresowań, wulgarny (2) (zależy gdzie), używanie wulgaryzmów, skłonność do nadmiernego przeklinania, inteligentny, uzdolniony $w$ każdej dziedzinie. Do opisu wyglądu zewnętrznego „typowego" Polaka studenci przytaczają 15 jednostek językowych, które odnoszą się do aspektu fizycznego ${ }^{20}$.

Autostereotypowy obraz ,prawdziwego" Polaka jest rekonstruowany na podstawie jednostek językowych zaproponowanych przez 141 studentów $(71,6 \%)$.

${ }^{19}$ Studenci podają też negatywne określenia ,typowego” Polaka w świetle aspektu politycznego: niezainteresowany sprawami kraju, robienie z siebie ofiary narodów, pogardliwy dla innych narodów, musi czuć nad kimś władzę.

${ }^{20}$ Autostereotypowy obraz „typowego” Polaka w świetle aspektu fizycznego nie jest jednolity, np. jasna karnacja, stowiańska uroda, biała urody, otyly. W innych przypadkach Polakowi studenci przypisują skarpetki połaczone z sandałami (6) (w przypadku mężczyzn), kamizelkę, charakterystyczne stroje ludowe, wianek, kolorowa suknię. Kategorię typowości reprezentuje jedna odpowiedź studencka zawierająca rzeczowniki w liczbie mnogiej (Polki, mężczyźni): ładne Polki i przystojni mężczyźni. 
$\mathrm{Na}$ to pytanie nie odpowiedziało 56 studentów (28,4\%). Aspekt psychospołeczny przedstawiają takie cechy ,prawdziwego" Polaka: pracowity (26), pracoholik, złota raczka, dobry w tym, co robi, wyróżnia się pracowitościa i sumiennościa, większa chęć zdobywania pozycji w pracy, stara się tak pracować aby się nie napracować, leniwy (4), mate zaangażowanie do pracy. Wyodrębniamy również cechę gościnność (24), „prawdziwego” Polaka. Stosunek „prawdziwego” Polaka do pieniędzy charakteryzują takie jednostki z aspektu psychospolecznego: podporzadkowanie całego świata, aby zdobywać jak największe zarobki; lubi się bogacić, siebie skupiony na zdobywaniu majątku; skapy (4); przesadna oszczędność. W przeciwieństwie do „typowego" Polaka, dla „prawdziwego” cecha pice alkoholu jest reprezentowana tylko przez 10 jednostek językowych, np. $z$ mocna głowa (2), radzenie sobie z duża ilościa alkoholu, alkoholik (3). W porównaniu do „typowego" Polaka, ,prawdziwemu” przypisuje się więcej jednostek określających „rodzinność” (7). Pojawiają się też cechy „prawdziwego" Polaka lubiącego rozrywkę: lubi się bawić, lubi bawić się przy muzyce, rozrywkowy, imprezowicz, lubi zabawe jak prawdziwi Stowianie etc. Do aspektu kulturowego dla „prawdziwego" Polaka - w przeciwieństwie do „typowego" - odnosi się więcej jednostek o nacechowaniu pozytywnym, np. dotyczących kultury osobistej: uprzejmy (5), kulturalny (3), posiada kulture osobista (2) etc. Jak w przypadku ,typowego" Polaka pojawiają się też jednostki określające przekonania religijne: katolik (3), bardzo religijny (3), wierzacy, znający wzorce chrześcijańskie i szanuje je (ale nie musi być wierzacy, chodzi o tradycję). Pojawia się więcej cech pozytywnych dotyczących inteligencji „prawdziwego” Polaka: inteligentny (3), ciekawy świata (3), mądry, zdolny, dba o rozwój osobisty. Potwierdzają się równie negatywne cechy, wymienione wcześniej także dla „typowego" Polaka: wulgarny (2), przeklina dużo (2), stabo oczytany, brak ogólnej wiedzy o świecie. Warto też zaznaczyć, że na podstawie cech ,prawdziwego" Polaka wyodrębnia się aspekt lokatywny: emigrowat z Polski, ma niechęć do mieszkania w Polsce. Do aspektu politycznego odsyłają jednostki językowe charakteryzujące "prawdziwego" Polaka jako patriotę: patriota (28), ma poczucie patriotyzmu, kocha swój kraj, dba o dobro kraju, przywiazany do ojczyzny, przywiazany do kraju, wierzacy w swój kraj etc. „Prawdziwy” Polak, według studentów, też zna hymn, świadomy historii narodu (2). Obraz „prawdziwego” Polaka od „typowego” różnią jednostki określające stosunek do polityki: lubiacy rozmawiać na temat polityki, zaangażowany w sprawy kraju, nie głosuja na PIS (2), nie szanuje Korwina, zaangażowania w sprawy państwa. Pojawiają się też określenia negatywne: narzekający na władzę (2), zapatrzony w władzę. Pojedyncze jednostki do określenia „prawdziwego" Polaka z aspektu politycznego mogą być uważane za jednostki odnoszące się do innych aspektów, np. kulturowego: związany z ojczyzna, tradycja, kultura. Do aspektu komunikacyjno-psychicznego odnosi się 95 jednostek o konotacji pozytywnej i 70 jednostek o konotacji negatywnej. Jak widać, jed- 
nostki o znaczeniu dodatnim dominują nad jednostkami o znaczeniu ujemnym, co potwierdza wpływ modyfikatora „prawdziwy” na wyobrażenia stereotypowe. Przytoczymy cechy dodatnie o frekwencji 3 i wyżej: pomocny (12), tolerancyjny (11) (wobec inności), uczciwy (8), honorowy (5), życzliwy (3) towarzyski (3), odważny (3), empatyczny (4), zaradny (4), mity (3), otwarty na innych (4), otwarty (3) etc. Studenckie charakterystyki (pojawiające się w odpowiedziach więcej niż 2 razy) ,prawdziwego" Polaka o znaczeniu negatywnym to nietolerancyjny (6), narzekajacy (5), smutny (4), niezadowolony (3), uparty (3). Aspekt fizyczny jest reprezentowany przez 6 jednostek językowych: ładna uroda (2), blada karnacja, skarpety z sandałami, piękny, ksztaltna kobieta.

Na pytanie o „typowego" Ukraińca odpowiedziało 173 (87,8\%) studentów, a nie udzieliło odpowiedzi 24 (12,2\%). W świetle aspektu komunikacyjno-psychicznego ,typowy” Ukrainiec jest charakteryzowany poprzez 128 jednostek językowych o konotacji pozytywnej oraz 63 jednostki o nacechowaniu negatywnym. Do ilustracji heterostereotypowego modelu „typowego" Ukraińca podajemy cechy o frekwencji wyżej niż 3 poświadczenia. Pozytywne określenia „typowego" Ukraińca sprowadzają się do następujących: otwarty (11), mily (9), pomocny (9), wesoly (7), uśmiechnięty (7), sympatyczny (8), życzliwy (5), skromny (5), towarzyski (5), wytrwaty (5), szczery (3), spokojny (3), cichy (3) etc. Typowość cech potwierdza odpowiedź zawierająca wyraz często: często sa mili i pomocni. Do opisu ,typowego" Ukraińca studenci używają cech negatywnych, np. gadatliwy (3), cwaniak (3), niekiedy nachalny (3) etc. „Typowego” Ukraińca postrzega się też w świetle aspektu psychospołecznego poprzez 75 jednostek językowych. Cechę ,pracowitość” Ukraińców potwierdzają jednostki: pracowity (61), sq to osoby pracowite, skory do pracy, chętny do pracy (3), w szybkim tempie wykonujacy obowiazki, dziela się na bardzo pracowitych albo tych leniwych, najlepiej wykonuje swoje obowiazki etc. Na obraz Ukraińca lubiącego zabawę składają się jednostki typu: lubiący się bawić (2), lubiący rozrywkę etc. „Typowy” Ukrainiec to też zwiazany z rodzina (2), przywiazany do rodziny, gościnny (6) etc. Na cechę „pijący” składa się 14 jednostek językowych typu lubiacy alkohol (5), ma mocna głowę (2) etc. Do aspektu kulturowego odsyła 46 jednostek językowych. Są to m.in. pozytywne i negatywne charakterystyki ,typowego" Ukraińca dotyczące kultury osobistej - uprzejmy (3), kulturalny, grzeczny, wychowany, a także - nieuprzejmy, niekulturalny (7). Kolejny zestaw jednostek dotyczy znajomości przez Ukraińca języków: mówi po ukraińsku (2), dobrze znaja język polski (na terenie Polski), biegle mówiacy po rosyjsku, w Polsce miłowanie języka ukraińskiego, nie rosyjskiego, udaje, że nie rozumie polskiego, żeby coś zyskać, nie mówi po polsku. „Typowy” Ukrainiec w opinii studentów ma akcent (2), inny język (2), ma śpiewny akcent, charakterystyczny akcent, typowa mowę, specyficzny sposób mówienia, lekkie przeciaganie wyrazów, cechy języka - zaciaganie etc. O stosunku „typowego” Ukraińca do kultury/tradycji ukraińskiej świadczą następują- 
ce cechy: przywiazany do swojej kultury (3), przywiązany do tradycji (2). Jeden $\mathrm{z}$ respondentów pisze: często dosyć zamknięci na kulturę Europy Zachodniej. Studencki punkt widzenia potwierdzają określenia typu młody student oraz zarazem na podstawie moich znajomych z Ukrainy - wykształcony (2). Aspekt fizyczny dla „typowego" Ukraińca jest bardziej rozbudowany o jednostki językowe (20) niż analogiczny aspekt dla „typowego" Polaka. Na heterostereotypowy model „typowego" Ukraińca składają się przykłady takie jak: zazwyczaj bardzo ładnie się ubieraja (2), uroda, zty gust, specyficzny styl ubierania (2), ubrany nieco niechlujnie (2), potężna budowa ciata, maja ułożone usta bardziej $w$ dziubek etc. W dwóch odpowiedziach charakteryzuje się wygląd kobiety: kobiety sa bardzo delikatnej urody; Ukrainka - mocny makijaż, dużo biżuterii. Jeden student twierdzi: podobny do Polaka (również Stowianin). 7 razy dla „typowego" Ukraińca pojawiają się cechy z aspektu politycznego. Cechy te charakteryzują „typowego" Ukraińca ze względu na patriotyzm, postawę obywatelską oraz stosunek do historii ukraińskiej: patriota, przywiązany do ojczyzny, dumny z pochodzenia, bardzo wyraźna tożsamość narodowa, szacunek do własnej historii, nieznajacy sprawy rzezi wołyńskiej $i$ UPA. O aspekcie lokatywnym „typowego” Ukraińca świadczą 2 jednostki językowe: sasiad, nie mieszka w swoim kraju.

Pytanie o „prawdziwego" Ukraińca umożliwiło wyodrębnienie 51 jednostek językowych z odpowiedzi 120 (60,9\%) studentów, nie odpowiedziało na nie jednak 77 osób (39,5\%). Aspekt psychospołeczny prezentują cechy, które są podobne do cech „typowego" Ukraińca: pracowity (43), gościnny (3) etc. Jednak cecha ,rodzinność” otrzymała większą reprezentację: rodzinny (5). Cecha leniwy pojawiła się tylko 1 raz w przeciwieństwie do „typowego” obrazu, przy którym pojawia się ona 4 razy. Na cechę „pijący” składa się 5 jednostek. Do aspektu kulturowego odnosi się 26 jednostek, które korelują z tymi wyodrębnionymi dla „typowego" Ukraińca. Są to cechy określające mówienie Ukraińca i znajomość przez niego języków: język (2), akcent (4) (reszta to stereotypy), ze śpiewnym stowiańskim akcentem (cecha wymowy), charakterystyczny akcent, świetnie mówi po polsku, mówiacy w języku rosyjskim i ukraińskim, unikanie rosyjskiego języka etc. O kulturze osobistej ,prawdziwego" Ukraińca świadczą cechy grzeczny (2), kulturalny, uprzejmy, niekulturalny (2). Jak widać, ,prawdziwemu” Ukraińcowi w tym aspekcie studenci przypisują mniej negatywnych cech dotyczących kultury osobistej. Niektóre jednostki mogą odnosić się do innych aspektów, np. politycznego - posiada te wszystkie unikatowe elementy tworzace kulturę i państwo czy psychospołecznego - wykazujacy chęć uczenia się i podejmowania pracy. Dla „prawdziwego" Ukraińca w aspekcie komunikacyjno-psychicznym pozytywne cechy (90) dominują nad negatywnymi (28). Przedstawiamy pozytywne cechy pojawiające się więcej niż 3 razy: otwarty (12), mity (6), pomocny (5), zaradny (5), towarzyski (4), uśmiechnięty (3), skromny (3), wesoly (3), sympatyczny (2), szczery (3). Dwukrotnie są notowane tylko 3 cechy negatywne: wybuchowy (2), 
nachalny (2), spontaniczny (2). Zestaw jednostek językowych odnoszonych do aspektu politycznego określa patriotyzm ,prawdziwego” Ukraińca: patriota (3), oddany dla kraju, przywiazany i oddany swojemu kraju, mało patriotyczny etc. Jednak w większym stopniu „prawdziwemu” Ukraińcowi przypisuje się dumę z pochodzenia, znajomość historii: świadomy swojego pochodzenia i dorobku kulturalnego Ukrainy, dba o pamięć swojej historii i tradycji kraju, szanujący swoje pochodzenie $i$ kulturę, nie wstydzi się skąd pochodzi etc. W świetle aspektu fizycznego ,prawdziwy” Ukrainiec jest charakteryzowany przez następujące jednostki (9): wytrwaty (2), potężna budowa ciata, delikatny, charakterystyczny wyglad, ciemne oczy, dtugie włosy, powabne włosy, wianek. Aspekt lokatywny jest przedstawiony tylko przez jedną podaną cechę - mieszka na terenie Ukrainy. Cechy „typowego" i prawdziwego" Polaka/Ukraińca wyodrębnione w poszczególnych aspektach pokazują, jakie wartości są ważne dla polskiej młodzieży.

\section{WNIOSKI}

Analiza studenckich definicji etnonimów Polak i Ukrainiec przekonuje, że w świadomości studentów Wydziału Filologicznego Uniwersytetu Łódzkiego obecne są różne sposoby ich kategoryzacji (Wykres 1): geograficzny, polityczny, tożsamościowy, narodowościowy, etniczny, etyczny, językowy oraz wartościowanie. Studenci najczęściej stosują kategoryzację geograficzną zarówno do określania Polaka (43,4\%), jak i Ukraińca (49,7\%). Jednak w ujęciu heterostereotypowym ten sposób kategoryzowania przeważa nad autostereotypowym o 6,3\%. Kategoryzacja etniczna częściej pojawia się w definicjach leksemu Ukrainiec $(32,5 \%)$ niż Polak (24\%). Natomiast kategoryzacja tożsamościowa dominuje w studenckich definicjach etnonimu Polak (12,75\%) (w przeciwieństwie do definicji etnonimu Ukrainiec (6,6\%)). W przypadku etnonimu Polak kategoryzacja polityczna (40,3\%) ma większą reprezentację niż w przypadku etnonimu Ukrainiec $(25,8 \%)$. Kategoryzacja językowa $(6,6 \%)$ i etyczna $(6,6 \%)$ dominują w definicjach określających Polaka nad definicjami z kategoryzacją językową (4,06\%) i etyczną $(4,06 \%)$ określających Ukraińca. Wartościowanie w obu przypadkach otrzymuje prawie jednakową reprezentację: dla Ukraińca - 9,6\%, dla Polaka-9,7\%. Ustalono, że kategoryzacja narodowościowa w ujęciu procentowym dla Polaka $(11,2 \%)$ jest tylko o $0,5 \%$ większa niż dla Ukraińca (10,7\%). Na tle wyrażeń o tym samym odniesieniu, co nazwy Polak i Ukrainiec, silnie wyróżniają się jednostki językowe odzwierciedlające binarną opozycję „swój-obcy/inny”. W ujęciu autostereotypowym są to wyrazy typu rodak, krajan, brat, nasz, swój, w ujęciu zaś heterostereotypowym są to leksemy i wyrażenia obcokrajowiec, cudzoziemiec, inny, osoba ze wschodu etc. W modelu heterostereotypowym pojawiają się też nazwy 
Ukraińca wyrażające przyjazne nastawienie i konotację pozytywną - brat/siostra ze wschodu, a także określenia Ukraińca jako sąsiada - sąsiad ze wschodu, sąsiad Polski. Studencki punkt widzenia oraz postrzeganie Ukraińca w dziedzinie edukacji ilustrują nazwy erazmus, erazmusy, koleżanka ze studiów. Autoidentyfikacja Polaka pojawia się częściej niż dla Ukraińca za pomocą nazw Stowianin, Stowian$k a$, a także przez przypisywanie tylko Polakowi nazwy Europejczyk. Historycznie markowane nazwy różnią oba podejścia, ponieważ dla Ukraińca proponuje się leksemy rusek, rusin, kozak, a dla Polaka - Lach, Lechita. Warto też odnotować, że nazwy historyczne nie przeważają na tle innych, co być może świadczy o ich nieutrwaleniu $\mathrm{w}$ świadomości językowej polskiej młodzieży. Wprowadzenie do pytań ankietowych modyfikatorów „typowy” i ,prawdziwy” umożliwiło zaobserwowanie różnic między „typowym” a „prawdziwym” obrazem Polaka/Ukraińca. Zarówno obraz „typowego" Polaka, jak i „typowego" Ukraińca zawiera więcej cech negatywnych w przeciwieństwie do „prawdziwego" (Wykres 2, Wykres 3). "Prawdziwemu" Polakowi studenci przypisują więcej cech dotyczących rodzinności, pracowitości, patriotyzmu oraz pogladów politycznych. „Prawdziwy” Ukrainiec, w opinii studentów, też jest bardziej rodzinny, kulturalny, dumny z pochodzenia, świadomy historii swojego kraju.

Zrekonstruowane na podstawie danych ankietowych cechy autostereotypu Polaka i heterostereotypu Ukraińca będą przydatne nie tylko do późniejszych badań o podobnym charakterze, lecz także - z pragmatycznego punktu widzenia - będą służyć jako tło przy wyborze określonego podejścia do nauki języka polskiego jako obcego. Tak więc materiały dydaktyczne mogą zawierać odpowiednie słownictwo dotyczące osobliwości komunikacyjno-psychicznych, kulturowych, politycznych człowieka etc. Przyczynkiem do aktualnych dyskusji na zajęciach ewentualnie może być także rozumienie wyrazów „typowy” i „prawdziwy”. Wyodrębnione kategoryzacje pomogą wybrać informacje, które powinny się pojawić przy budowaniu wizerunku bohatera w nowych materiałach do nauki języka polskiego. Rozumienie przez Ukraińców uczących się języka polskiego zarówno cech pozytywnych (np. pracowity, gościnny, rodzinny, otwarty i in.), jak i negatywnych (np. leniwy, gadatliwy, niekulturalny, zamknięty na kulture Europy) może być przydatne do adaptacji Ukraińców w środowisku polskojęzycznym. Warto też podkreślić, że i autostereotyp Polaka zawiera sporo cech negatywnych, świadczących także o dostrzeganiu wad także u siebie, a nie tylko u innych. Temu celowi służyć może cały zestaw przywoływanych w niniejszym opracowaniu wyobrażeń polskiej młodzieży studenckiej na temat stereotypu Ukraińca. Znajomość cech „typowego" Ukraińca: nie zna języka polskiego oraz udaje, że nie rozumie polskiego, żeby coś zyskać może wpłynąć na zwiększenie motywacji do nauki języka polskiego przez osoby z Ukrainy. Uświadomienie przez osoby z Ukrainy pozytywnych składników obrazu Ukraińca jako wykształconego, młodego studenta oraz kolegi z grupy, erazmusa sprzyjać będzie motywacji do zdobywa- 
nia wykształcenia wśród ukraińskiej młodzieży. Świadomość używania przez młodzież określeń Stowianin, Stowianka w stosunku i do Polaka, i do Ukraińca może wpływać na budowanie poczucia wspólnotowego przy kształceniu międzykulturowym. Zapoznanie się z jednakowymi cechami możliwymi i pożądanymi dla „prawdziwego” Polaka i Ukraińca może służyć jako czynnik integracyjny w grupie polsko-ukraińskiej, który wprowadzi młode osoby ukraińskojęzyczne do świata wartości polskiej młodzieży i będzie służył nawiązywaniu kontaktów językowych i kulturowych między młodymi Polakami i Ukraińcami.

Wykres 1. Sposoby kategoryzacji etnonimów Polak/Ukrainiec w ujęciu procentowym

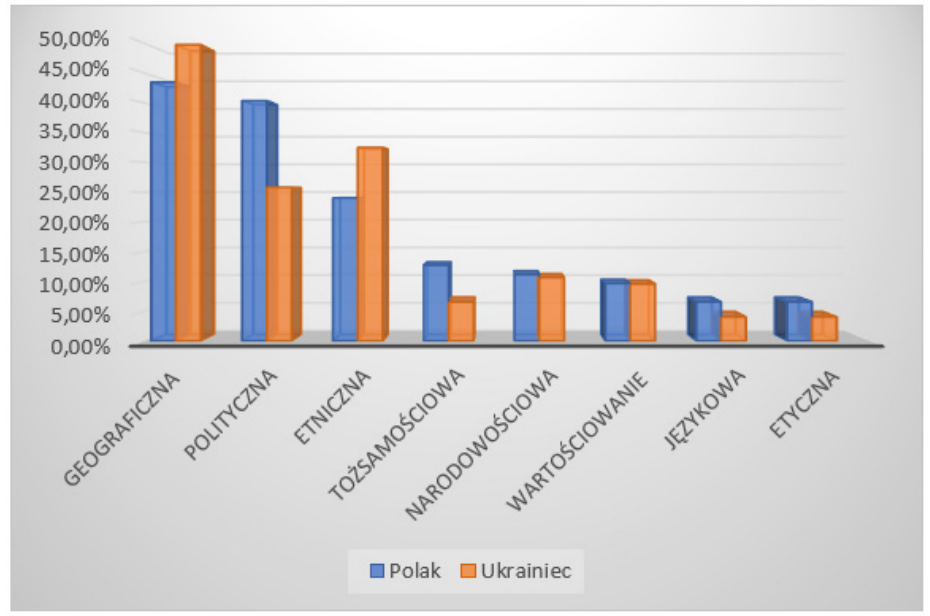

Źródło: opracowanie własne

Wykres 2. Cechy ,typowego" $i$,prawdziwego” Polaka w ujęciu procentowym

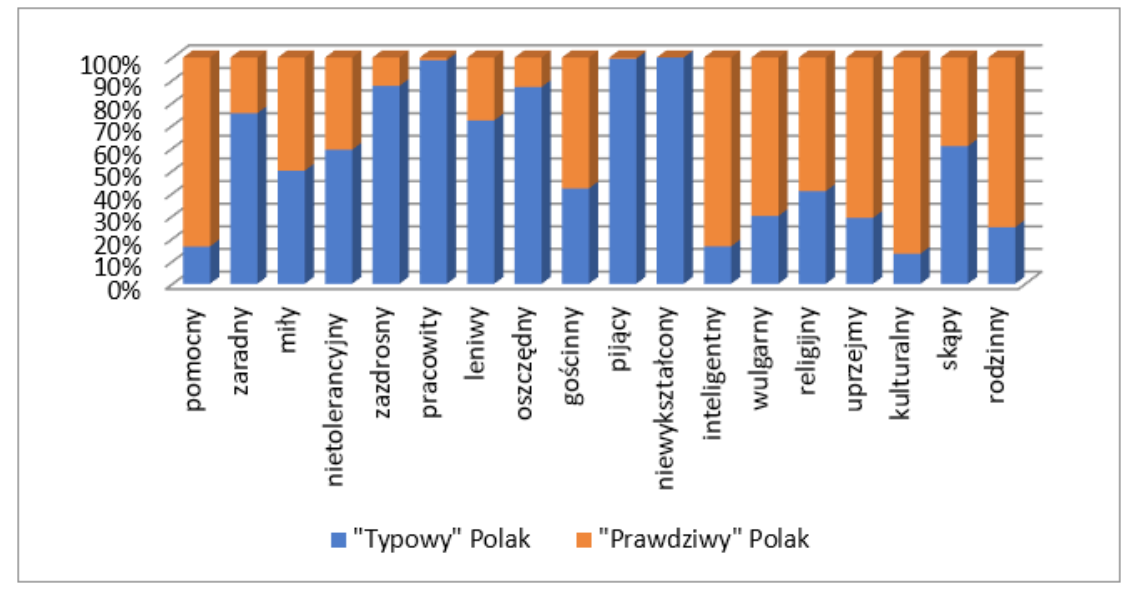

Źródło: opracowanie własne 
Wykres 3. Cechy „typowego” $i$,,prawdziwego” Ukrainca w ujęciu procentowym

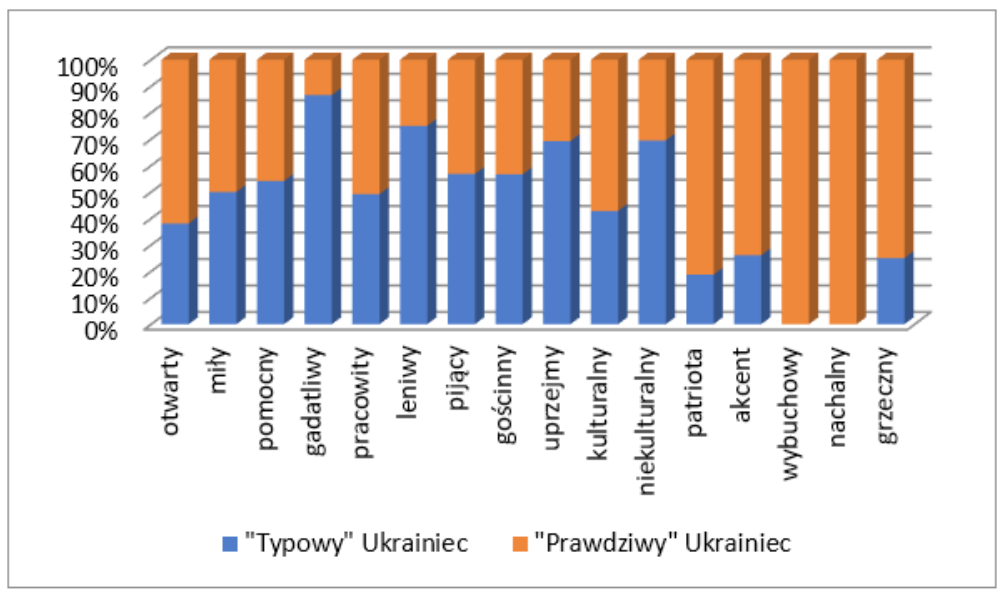

Źródło: opracowanie własne

\section{WYKAZ SKRÓTÓW}

ISJP - Inny słownik języka polskiego PWN, 2014, pod red. M. Bańki, t. 1-2, Warszawa.

USJP - Uniwersalny stownik języka polskiego, 2003, pod red. S. Dubisza, t. 1-4, Warszawa.

WSJP - Wielki słownik języka polskiego [online] http://www.wsjp.pl/ [05.06.2020].

WSJP - Wielki stownik języka polskiego, 2018, pod red. S. Dubisza, t. 1-5, Warszawa.

WSO - Wielki stownik ortograficzny PWN, 2011, pod red. E. Polańskiego, Warszawa.

WSU - Wielki słownik ucznia, 2008, pod red. M. Bańki, t. 1-2, Warszawa.

$\mathrm{KG}$ - kategoryzacja geograficzna

$\mathrm{KP}$ - kategoryzacja polityczna

$\mathrm{KE}$ - kategoryzacja etyczna

KEtn - kategoryzacja etniczna

$\mathrm{KJ}$ - kategoryzacja językowa

$\mathrm{KN}$ - kategoryzacja narodowościowa

W - wartościowanie

\section{BIBLIOGRAFIA}

Bartmiński J., 2001, Operatory ,typowy” i ,prawdziwy” w strukturze semantycznej tekstu, „Prace Filologiczne", t. XLV1, s. 41-47.

Bartmiński J., 2006, Semantyka i polityka. Nowy profil polskiego stereotypu Ukraińca, w: K. Ożóg, E. Oronowicz-Kida (red.), Przemiany języka na tle przemian wspótczesnej kultury, Rzeszów, s. 191-211. 
Bartmiński J., 2014, Ankieta jako pomocnicze narzędzie rekonstrukcji językowego obrazu świata, w: S. Niebrzegowska-Bartmińska, M. Nowosad-Bakalarczyk, S. Wasiuta (red.), Polskie wartości w europejskiej aksjosferze, Lublin, s. 309-332.

Bartmiński J., 2014, Wybrane koncepty w świetle danych ankietowych: Europa, Europejczyk, ojczyzna, Polska, Polak, świat, Wschód, Zachód, w: S. Niebrzegowska-Bartmińska, M. Nowosad- Bakalarczyk, S. Wasiuta (red.), Polskie wartości w europejskiej aksjosferze, Lublin, s. $248-308$.

Bartmiński J., 2015, Leksykon aksjologiczny Stowian i ich sąsiadów... - co zawiera, na jakich zasadach się opiera, dla kogo jest przeznaczony?, w: J. Bartmiński, I. Bielińska-Gardziel, B. Żywicka (red.), Leksykon aksjologiczny Stowian i ich sąsiadów, Lublin, s. 7-13.

Broniarek W., 2005, Gdy ci słowa zabraknie. Stownik synonimów, Warszawa.

Brzezowska M., 2008, Autostereotyp Polaka w wybranych podręcznikach języka polskiego dla cudzoziemców, „Postscriptum Polonistyczne”, nr 1 (13), s. 47-62.

Dąbrowska A., 1998, Czy istnieje w podręcznikach języka polskiego dla cudzoziemców wyraźny obraz Polski i Polaków? (Próba znalezienia stereotypów), w: J. Anusiewicz, J. Bartmiński (red.), Stereotyp jako przedmiot lingwistyki: teoria, metodologia, analizy empiryczne, Wrocław, s. 278-295.

Fylypets' O., 2019, Avtostereotyp poliaka i heterostereotyp ukrain'cia $v$ seredovyshchi toruns'kykh studentiv, w: M. Gębka-Wolak, A. Krawczuk (red.), Z bliska i z daleka. Język polski w badaniach językoznawców lwowskich i toruńskich, Toruń, s. 217-234.

Fylypets' O., 2019, Etnostereotypni uíavlennia pro poliaka i ukrain'cia sered studentiv Zheshivs'kogo universytetu (kriz' pryzmu asotsiatsil iz predmetamy), „Zeszyty Naukowe Prac Ukrainoznawczych", nr 3, s. 155-165.

Fyłypec O., 2020, Najnowszy stereotyp Ukraińca w środowisku studentów poznańskich i lubelskich (w druku).

Krawczuk A., 2008, Nowe profile ukraińskiego stereotypu Polaka (na podstawie ankietowania studentów lwowskich), „Postscriptum Polonistyczne”, nr 1 (1), s. 147-170.

Niebrzegowska-Bartmińska S., 2014, Od separacyjnego do holistycznego opisu językowego obrazu świata. Na marginesie dyskusji nad kształtem artykułów w Leksykonie aksjologicznym Stowian i ich sąsiadów, w: I. Bielińska-Gardziel, S. Niebrzegowska-Bartmińska, J. Szadura (red.), Wartości w językowo-kulturowyn obrazie świata Stowian i ich sąsiadów, t. 3., Lublin, s. $71-102$.

Nowosad-Bakalarczyk M., 2002, Kobieta ,typowa” $i$,prawdziwa” w oczach studentów: (przyczynek do stereotypu kobiety), „Język Polski”, z. 1 (LXXXII), s. 25-35.

PacławskaE., 2009, Ukrainiec woczach studentów na wschodzieizachodzie Polski, w: S. NiebrzegowskaBartmińska, S. Wasiuta (red.), Stereotypy w języku i w kulturze, Lublin, s. 65-80.

Piętkowa R., 2007, Językowy obraz świata i stereotypy a nauczanie języka polskiego, w: A. Achtelik, J. Tambor (red.), Sztuka czy rzemiosto? Nauczyć Polski i polskiego, Katowice, s. 85-104.

Stankiewicz K., Żurek A., 2010, Obraz Polki/Polaka w serii podręczników do nauczania języka polskiego jako obcego Hurra!!! Po polsku, „Acta Universitatis Lodziensis. Kształcenie Polonistyczne Cudzoziemców", t. 19, G. Zarzycka (red.), s. 495-505.

Szadura, J., 1993, Z badań nad autostereotypem Polaka: kryteria polskości, w: J. Bartmiński, M. Mazurkiewicz Brzozowska (red.), Nazwy wartości: studia leksykalno-semantyczne, Lublin, s. 239-256. 
Olga Fytypec

\title{
MODERN STEREOTYPE OF A POLE AND A UKRAINIAN IN THE OPINION OF STUDENTS OF PHILOLOGY OF THE UNIVERSITY OF LODZ (ON THE BASIS OF SURVEY STUDIES)
}

Keywords: stereotype of a Pole, stereotype of a Ukrainian, linguistic picture of the world, students of the Faculty of Philology, survey.

\begin{abstract}
The article presents a reconstruction - on a material of 394 surveys - of modern stereotypes of a Pole/Ukrainian among the students of the Faculty of Philology of the University of Lodz. An analysis of several points of more extensive questionnaire was proposed, namely: a request to provide a definition of a Pole/Ukrainian; expressions with the same reference as the Pole/Ukrainian; features of a "typical" and "real" Pole/Ukrainian. In student definitions of the name Pole/Ukrainian, geographical, ethnic, nationality categorization is more often used, while linguistic, ethical, and identity are used less often. The students consider lexeme Polachek, compatriot, countryman, ours, theirs and others, as equivalents of the word Pole and they give names instead of the word Ukrainian: foreigner, neighbour, brother from the east and others. The image of a "real" Pole/Ukrainian is more positive than the image of a "typical" representative of the nationality. Both for a Pole and a Ukrainian, the stereotypical image emerging from the survey data is ambivalent. The influence of national stereotypes on teaching Polish as a foreign language and the possibility of using the obtained data in glottodidactics were taken into account.
\end{abstract}

